\title{
Oxidative stress induces caspase-independent retinal apoptosis in vitro
}

\author{
RJ Carmody ${ }^{1}$ and TG Cotter ${ }^{*, 1}$ \\ 1 Tumour Biology Laboratory, Department of Biochemistry, Lee Maltings, \\ University College Cork, Cork, Ireland \\ * Corresponding author: TG Cotter, Tumour Biology Laboratory, Department of \\ Biochemistry, Lee Maltings, University College Cork, Cork, Ireland. Tel: 353- \\ 21-904068; Fax: 353-21-904259; Email: t.cotter@ucc.ie
}

Received 6.8.99; revised 24.11.99; accepted 30.11.99 Edited by C Borner

\begin{abstract}
Apoptosis is the mode of cell death in retinitis pigmentosa (RP), a heterogeneous group of retinal degenerations. The activation of the caspase proteases forms a pivotal step in the initiation and execution phase of apoptosis in many cells. Inhibition of caspases has been reported to prevent apoptosis in many model systems. However, we demonstrate the absence of caspase activation during retinal cell apoptosis in vitro which involves phosphatidylserine (PS) externalisation, DNA nicking and cell shrinkage. In addition, zVAD-fmk, DEVD-CHO and BD-fmk, inhibitors of the caspases, were unable to alter the characteristics or kinetics of apoptosis, implying that retinal cell death in vitro follows a caspase-independent pathway. We have previously demonstrated the ability of reactive oxygen species (ROS) to act as mediators of retinal cell apoptosis in vitro as well as the ability of antioxidants to prevent retinal cell apoptosis. Here we demonstrate the oxidative inactivation of caspases in this model of retinal apoptosis and provide evidence for an oxidative stress driven cell death pathway that does not involve caspase activity and which retains key features of apoptotic cell death. Furthermore, our data indicates that apoptotic events such as PS exposure, DNA nicking and cell shrinkage may occur independently of caspase activity. Cell Death and Differentiation (2000) 7, 282291.
\end{abstract}

Keywords: apoptosis; retina; retinitis pigmentosa; caspaseindependent; reactive oxygen species

Abbreviations: BD-fmk, t-butyloxycarbonyl-aspartate-fluoromethylketone; DAPI, 4'-6 diamindino-2-phenylindole dichloride; $\mathrm{DCFH} / \mathrm{DA}$, dichlorofluorescein diacetate; DEVD-CHO, aspartateglutamate-valine-aspartate-aldehyde; DEVD-pNA, aspartate-glutamate-valine-aspartate- $p$-nitroanilide; DTT, Dithiothreitol; GSH, Glutathione; JC-1, 5,5',6-6'-tetrachloro-1,1,3,3'-tetraethylbenzimidazole-carbocyanine iodide; PDTC, pyrrolidinedithiocarbamate;
$P S$, phosphatidylserine; $R O S$, reactive oxygen species; $R P$, retinitis pigmentosa; TUNEL, terminal dUTP nick end labelling; z-VAD-fmk, benzyloxycarbonyl-valine-alanine-aspartate-fluoromethylketone

\section{Introduction}

Apoptosis is a form of programmed cell death which enables a cell to direct its own destruction. This form of cell death appears to be crucial for mammalian development and subsequent tissue homeostasis. Inappropriate apoptosis has been implicated in several neurodegenerative diseases such as Alzheimer's, ${ }^{1}$ amyotrophic lateral sclerosis ${ }^{2}$ and Huntington's, ${ }^{1}$ as well as ischaemic damage ${ }^{3}$ and several forms of retinal degeneration collectively referred to as retinitis pigmentosa (RP). ${ }^{4-6} \mathrm{RP}$ is characterised by an initial loss of night vision followed by a progressive loss of peripheral and central visual acuity. Histologically, degeneration of rod photoreceptors is associated with night blindness while degeneration of cone photoreceptors correlates with loss of peripheral and central visual fields. The molecular genetics underlying the pathology of RP is highly heterogeneous and at least 15 genes have been implicated in the aetiology of RP to date (Http://www.sph.uth.tmc.edu/retnet). Several of the implicated genes are involved in the rod phototransduction cascade $^{7}$ while others have been ascribed a role in retinoid cycling in the retina. ${ }^{8,9}$ The exact mechanisms by which such genetic lesions result in the degenerative phenotype of RP is presently unclear however it is becoming evident that such diverse genetic defects converge on a common pathway for photoreceptor apoptosis. ${ }^{4-6}$ At present, apoptotic photoreceptor cell death appears to represent the only unifying feature of all forms of RP, with the implication that components of the apoptotic machinery may serve as potential therapeutic targets applicable to all forms of RP.

Genetic studies of the nematode $C$. elegans have identified two genes, ced-3 and ced-4, which are required for normal developmental cell death. ${ }^{10}$ A third gene, ced-9, was found to be a negative regulator of apoptosis and to act antagonistically to ced-3 and ced-4 to prevent cell death. ${ }^{10}$ Mammalian homologues of each of these genes have now been identified and are represented by the $b c /-2$ gene family (ced-9), ${ }^{11}$ Apaf-1 (ced-4) $)^{12}$ and the caspase gene family (ced-3). ${ }^{13}$ Caspase-1 was the first mammalian Ced-3 homologue identified ${ }^{13}$ in what is now an expanding family of cysteine proteases of which caspase- 3 displays the highest homology with the Ced-3 prototype. ${ }^{14}$ The caspases are believed to function in the effector stage of apoptosis following an initiating signal. ${ }^{15}$ Such signals may derive from the direct activation of death receptors such as $\mathrm{Fas}^{16}$ or from the release of cytochrome-c from mitochondria. ${ }^{17}$ Activation of caspases by cytosolic cytochrome-c requires the formation of an 'apoptosome' complex between cytochrome-c, Apaf-1 
and procaspase-9 in an ATP dependent manner. Both release of cytochrome-c and the activation of procaspase- 9 by Apaf-1 are inhibitable by $\mathrm{Bcl}-\mathrm{xL} .{ }^{18,19}$ Once activated caspase-9 may initiate a cascade of caspase activation which ultimately leads to apoptosis. ${ }^{20}$

Many targets of caspase activity have now been identified and give strong support for the role of caspases as effectors of the apoptotic programme. ${ }^{21}$ Caspase substrates include proteins which play a critical role in DNA replication, ${ }^{22,23}$ DNA repair ${ }^{24}$ cell survival signalling, ${ }^{25}$ as well as proteins which regulate cytoskeletal reorganisation and cellular disassembly. ${ }^{26,27} \mathrm{~A}$ caspase activated DNase (CAD) has also been identified; cleavage of its endogenous inhibitor (ICAD) by caspases allows its translocation to the nucleus where it catalyses the internucleosomal cleavage of chromosomal DNA. ${ }^{28}$ Much of the consequences of caspase activity have been determined using a range of synthetic and viral inhibitors. Such inhibitors have been demonstrated to inhibit apoptosis in a range of cell types using a variety of inducing stimuli. ${ }^{29}$ However, several studies have reported the inability of caspase inhibitors to prevent cell death in a number of model systems. ${ }^{30-36}$ These studies suggest that cells which have committed to caspase activation are destined to die and that while the inhibition of caspases may prevent certain morphological and biochemical features of apoptosis their ultimate fate is cell death.

In this study, we report the apoptosis of retinal cells in vitro via a pathway that does not involve caspase activation and can not be prevented by caspase inhibitors. We show that the generation of reactive oxygen species and oxidative stress during retinal cell death results in the oxidative inactivation of the caspases. The cell death that follows features phosphatidylserine (PS) exposure on the outer surface of the plasma membrane, DNA nicking and cell shrinkage, indicating that these apoptotic events occur independently from caspase activation.

\section{Results}

Phosphatidylserine exposure, DNA nicking and cell shrinkage in primary retinal cell culture. Absence of low molecular weight DNA fragmentation

The spontaneous apoptosis of primary retinal cells cultured under serum free conditions has previously been described with respect to DNA nicking, nuclear condensation and cell shrinkage ${ }^{37,38}$ (Figure 1B), all of which are established, characteristic, features of apoptosis. Approximately $75 \%$ of all cells in the mouse retina are photoreceptors, and $97 \%$ of these are rods. The remaining cells include retinal ganglion, bipolar, horizontal and amacrine cells. In this study we have analyzed other events typical of apoptotic retinal cell death such as exposure of PS on the outer leaf of the plasma membrane and low molecular weight, internucleosomal DNA fragmentation. Our data indicates that PS flipover is a feature of retinal cell death in vitro as measured by annexin-V-FITC binding (Figure 1A). However, low molecular weight, internucleosomal DNA fragmentation was not detected in retinal cell cultures using DNA agarose gel electrophoresis (Figure $1 \mathrm{C}$ ), despite the labelling of these cells using the terminal dUTP nick end labelling (TUNEL) assay which fluorescently labels $3^{\prime} \mathrm{OH}$ nicked ends in DNA (Figure 1D). This data indicates the presence of DNA strand nicks or possibly high molecular weight $(300-500 \mathrm{~kb})$ DNA degradation, as shown by the TUNEL assay, in the absence of low molecular weight fragmentation, as demonstrated by DNA gel electrophoresis, during in vitro retinal cell apoptosis. Analysis of nuclear morphology of retinal cells after $12 \mathrm{~h}$ in culture, using DAPI stained cells under a fluorescence microscope, demonstrates nuclear condensation and fragmentation as these cells undergo apoptosis (Figure 1E).

\section{Caspase inhibitors zVAD-fmk, DEVD-CHO and BD-fmk fail to prevent retinal cell apoptosis}

Caspase inhibitors have been widely reported to inhibit apoptosis in a large number of cell types induced to undergo apoptosis by a diverse range of stimuli. The apparent central role played by the caspases for the completion of the death program demonstrated in such studies prompted us to investigate their role in retinal cell apoptosis in vitro. Three peptide inhibitors of caspases were employed. DEVD-CHO has been reported to inhibit caspase- $3,-7,-1$ and $-4,{ }^{26}$ while the zVAD-fmk peptide has a broader spectrum of inhibition, effective against all caspases tested to date, including caspases-3, $-6,-8,-1,-2$ and -4 . The truncated zVAD-fmk analogue BD-fmk is a general cysteine protease inhibitor and has a still wider spectrum of inhibition against the caspases. The concentrations of Z-VAD-fmk, DEVD-CHO and BD-fmk used were 100,100 and $80 \mu \mathrm{M}$ respectively. The data shown in Figure $2 \mathrm{~A}$ demonstrates the failure of all three caspase inhibitors to prevent retinal cell apoptosis as assessed by annexin- $\mathrm{V}$ binding. Jurkat cells treated with an apoptosis inducing anti Fas IgM in the presence or absence of the caspase inhibitors z-VAD-fmk, DEVD-CHO and BD-fmk, were used as a control to demonstrate the efficacy of these inhibitors to prevent apoptosis at the concentrations employed (Figure 2B). In addition to this, the caspase inhibitors used did not alter the kinetics of the death process or any other features of apoptosis as described in Figure 1 (Figure 2A,C,D, and data not shown).

\section{Caspase- 3 is not activated during retinal cell apoptosis}

The failure of effective levels of caspase inhibitors to prevent apoptosis in retinal cultures encouraged us to investigate the activation status of the caspases during cell death. The activation of caspase-3 requires its proteolytic processing from the $32 \mathrm{kD}$ pro-enzyme to the $17 \mathrm{kD}$ active enzyme. Analysis of the levels of the 32 and $17 \mathrm{kD}$ caspase- 3 species using Western blot demonstrates the absence of active, $17 \mathrm{kD}$ caspase-3 in cell lysates taken from retinal cultures undergoing apoptosis (Figure 3). The murine haematopoeitic $32 \mathrm{D}$ cell line was employed to demonstrate the ability to detect the $17 \mathrm{kD}$ caspase-3 form, which was detectable following ultra violet irradiation of these cells (Figure 3). These data suggest that the failure of caspase inhibitors to prevent 
retinal apoptosis is due to the non-participation of caspases in the death program of these cells. In addition to this, the levels of procaspase-3 present in retinal cells is significantly lower than that found in the murine haematopoietic 32D cell line (Figure 3). The differences in caspase-3 levels observed between these two cell types may be a reflection of the differences in the natural propensity of a dividing, short-lived haematopoietic cell and a post-mitotic, irreplaceable neuronal cell to activate the apoptotic death program. ${ }^{39}$

\section{Caspases are oxidatively inactivated during retinal cell death}

We have previously demonstrated a crucial role for reactive oxygen species (ROS) as mediators of retinal cell apoptosis in vitro. $^{38}$ This, together with studies demonstrating the sensitivity of caspases to redox state alterations, ${ }^{40}$ suggested that the inactivation of caspase-3 during retinal cell apoptosis may be due to oxidative modification. Figure 4A demonstrates the ability of peroxide to inactivate the caspase activity in a cytosolic extract from anti-Fas IgM treated Jurkat cells. Jurkat cells were treated with apoptosis inducing antiFas IgM antibody and total cellular protein extracted. Jurkat cell lysates were then treated with increasing concentrations of hydrogen peroxide (50 to $800 \mathrm{mM}$ ) for $30 \mathrm{~min}$ at $4^{\circ} \mathrm{C}$. Subsequent analysis of caspase activity as described in Materials and Methods demonstrated the inhibition of caspase (DEVDase) activity with increasing concentrations of hydrogen peroxide. Fifty $\mathrm{mM}$ hydrogen peroxide reduced caspase activity in anti-Fas treated Jurkat cell lysates by
A

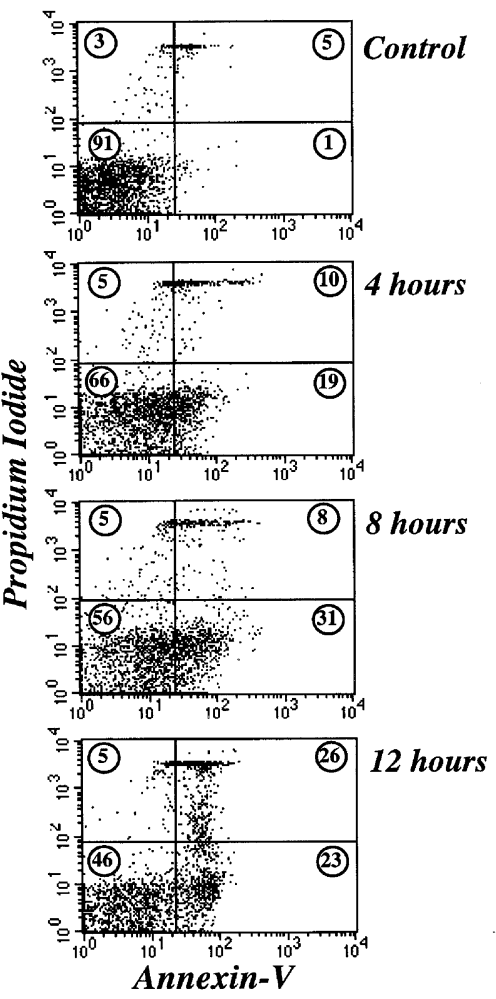

B

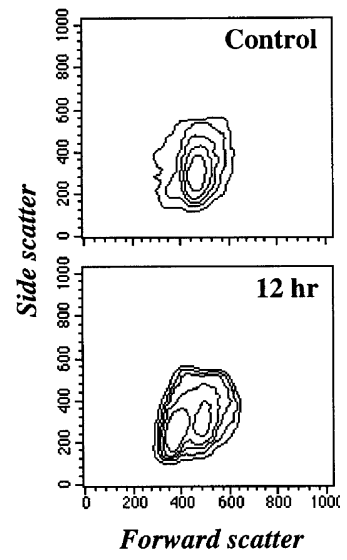

C

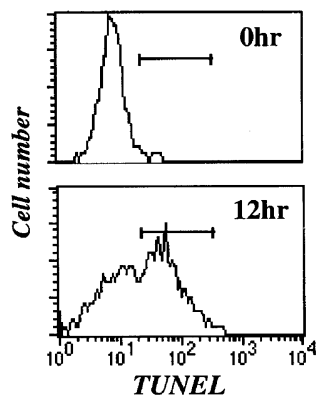

D

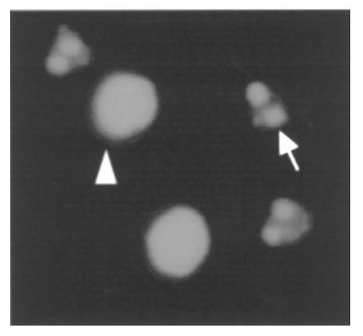

$\mathbf{E}$

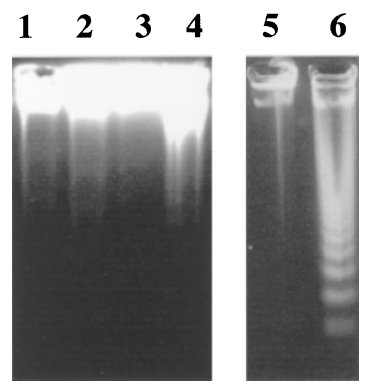

Figure 1 Phosphatidylserine (PS) exposure, cell shrinkage, and DNA nicking occur in the absence of low molecular weight, internucleosomal, DNA fragmentation during retinal cell death in vitro. (A) Retinal cell cultures show increased annexin-V-FITC binding over time ( 0 to $12 \mathrm{~h})$ due to exposure of PS on the outer leaflet of the plasma membrane. This increase in annexin-v binding is followed by increased membrane permeability to propidium iodide (PI) due to secondary necrosis. (B) Retinal cells also display cell shrinkage over $12 \mathrm{~h}$ in culture as determined by a decrease in the forward and side light scattering properties of these cells. Forward and side scatter may be used as a measure of cell size and granularity respectively. (C) Low molecular weight, internucleosomal DNA fragmentation was not detected following 1.5\% agarose electrophoresis of retinal cell extracts at 0, 4, 8 and $12 \mathrm{~h}$ (lanes 1, 2, 3, 4 respectively). Untreated and anti-Fas IgM treated ( $300 \mathrm{ng} /$ $\mathrm{ml}$ for $4 \mathrm{~h}$ ) Jurkat cell extracts (lanes 5 and 6 respectively) analyzed in the same way serve as negative and positive controls for DNA fragmentation respectively. (D) DNA nicking in retinal cells measured immediately after isolation and following $12 \mathrm{~h}$ in culture using the TUNEL assay which allows the fluorescent labelling of 3 'OH ends on DNA. (E) DAPI staining of retinal cells $12 \mathrm{~h}$ after introduction into culture demonstrates the appearance of nuclear apoptotic morphology. Normal cell displays a diffuse nuclear staining with DAPI (arrowhead), while apoptotic nuclei are condensed and fragmented (arrow). The appearance of cells with apoptotic nuclear morphology coincided with the detection of TUNEL labelled and shrunken cells by flow cytometry 


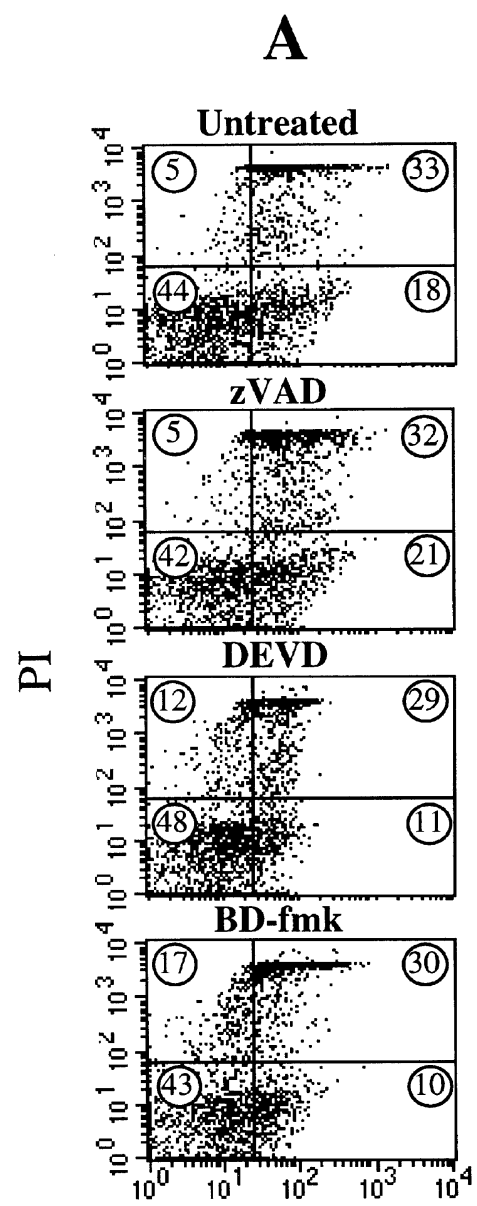

Annexin-V

\section{B}

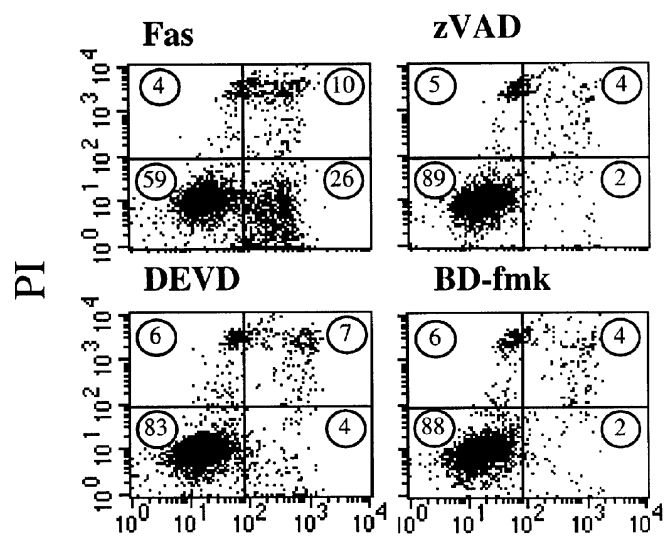

Annexin- $V$

Figure 2 The caspase inhibitors zVAD-fmk, DEVD-CHO and BD-fmk do not prevent retinal cell death in vitro. (A) Treatment of retinal cell cultures with the caspase inhibitors does not prevent PS exposure. Retinal cells were incubated in the presence and absence of ZVAD-fmk (100 $\mu \mathrm{M})$, DEVD-CHO (100 $\mu \mathrm{M})$ and BDfmk $(80 \mu \mathrm{M})$ and PS exposure measured by annexin-V binding after $12 \mathrm{~h}$ in culture. (B) zVAD-fmk $(100 \mu \mathrm{M})$, DEVD-CHO $(100 \mu \mathrm{M})$ and BD-fmk $(80 \mu \mathrm{M})$ prevent PS exposure and apoptosis in anti-Fas lgM ( $300 \mathrm{ng} / \mathrm{ml}$ for $4 \mathrm{~h})$ treated Jurkat cells. (C) zVAD-fmk (100 $\mu \mathrm{M})$, DEVD-CHO $(100 \mu \mathrm{M})$ and BD-fmk (80 $\mu \mathrm{M})$ do not prevent retinal cell shrinkage measured after $12 \mathrm{~h}$ in culture. (D) DNA nicking in retinal cell cultures (measured after $12 \mathrm{~h}$ in culture), as determined by TUNEL, is not prevented by zVAD-fmk $(100 \mu \mathrm{M})$, DEVD-CHO $(100 \mu \mathrm{M})$ and BD-fmk $(80 \mu \mathrm{M})$ 
approximately $55 \%$ while $100 \mathrm{mM}$ decreased caspase activity by approximately $75 \%$ (Figure $4 \mathrm{~A}$ ). It has been suggested that a critical cysteine group in the active site of the caspases makes them sensitive to thiol oxidation. ${ }^{41}$ In order to investigate the means of caspase inactivation in cell lysates from Fas treated Jurkat cells incubated with peroxide, we determined the ability of the thiol reducing agent dithiothreitol (DTT) to restore caspase activity. As Figure 4B demonstrates, incubation of hydrogen peroxide $(200 \mathrm{mM})$ treated lysates from anti-Fas treated Jurkat cells with 100 and $200 \mathrm{mM}$ DTT restores caspase activity. This provides further evidence for the ability of ROS to inactivate the caspases through thiol oxidation. To determine whether oxidative inactivation of the caspases was responsible for their non-participation in retinal cell apoptosis we repeated this experiment using lysates recovered from retinal cells as they underwent apoptosis in vitro. Figure 4C shows that 100 to $400 \mathrm{mM}$ DTT is capable of restoring caspase activity in retinal cell lysates in a manner similar to that seen in peroxide treated Jurkat lysates. While the concentrations of both hydrogen peroxide and DTT used in these experiments is quite high it is likely that lower concentrations would have yielded similar results if the incubation times were extended. These data suggest that the lack of caspase activation observed in retinal cells as they undergo apoptosis in culture is due to the oxidative inactivation of the caspases, most likely at the thiol group in the active site of these enzymes.

\section{Reactive oxygen species (ROS) generation is an early event and precedes mitochondrial membrane potential disruption in retinal cell apoptosis}

The involvement of ROS in photoreceptor apoptosis in vitro has previously been established ${ }^{38}$ (and Table 1). As Figure $5 \mathrm{~B}$ shows, the generation of intracellular ROS is an early event in retinal cell apoptosis in vitro with increased peroxide levels detectable as early as $2 \mathrm{~h}$ following introduction into culture. The loss of mitochondrial membrane potential has
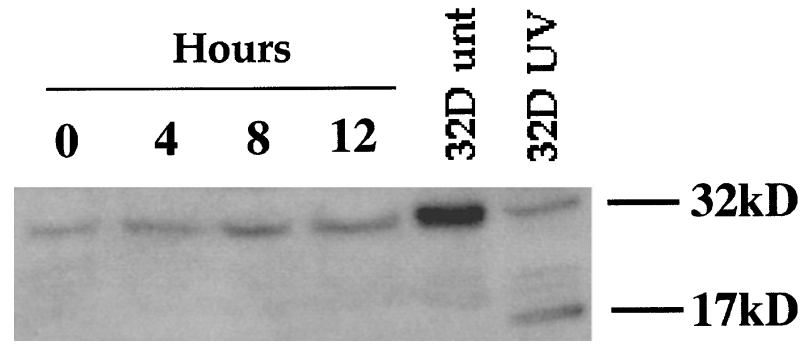

Figure 3 Immunoblot analysis of caspase-3 demonstrates absence of caspase- 3 activation as retinal cell cultures undergo cell death. Equivalent quantities of total protein from retinal cell lysates taken at $0,4,8$ and $12 \mathrm{~h}$, and untreated and UV treated 32D cells were resolved using SDS-PAGE and transferred to a nitrocellulose membrane. The presence of pro-caspase-3 $(32 \mathrm{kD})$ and the proteolytically active $17 \mathrm{kD}$ species were determined by immunoblot analysis using anti-caspase- 3 antibody. Protein extracts from retinal cultures were isolated following 4,8 , and $12 \mathrm{~h}$ of culture, as well as freshly isolated retinal cells $(0 \mathrm{~h})$. While the $32 \mathrm{kD}$ pro-caspase species is present at all time points analyzed, the active $17 \mathrm{kD}$ species is absent up to $12 \mathrm{~h} .32 \mathrm{D}$ cells demonstrate the processing of pro-caspase-3 $(32 \mathrm{kD})$ to the active $17 \mathrm{kD}$ fragment as these cells undergo apoptosis. 32D protein lysates extracted $16 \mathrm{~h}$ after a $10 \mathrm{~min}$ exposure to ultraviolet irradiation

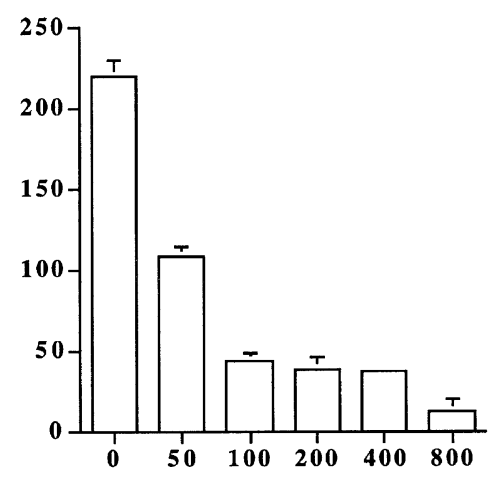

A
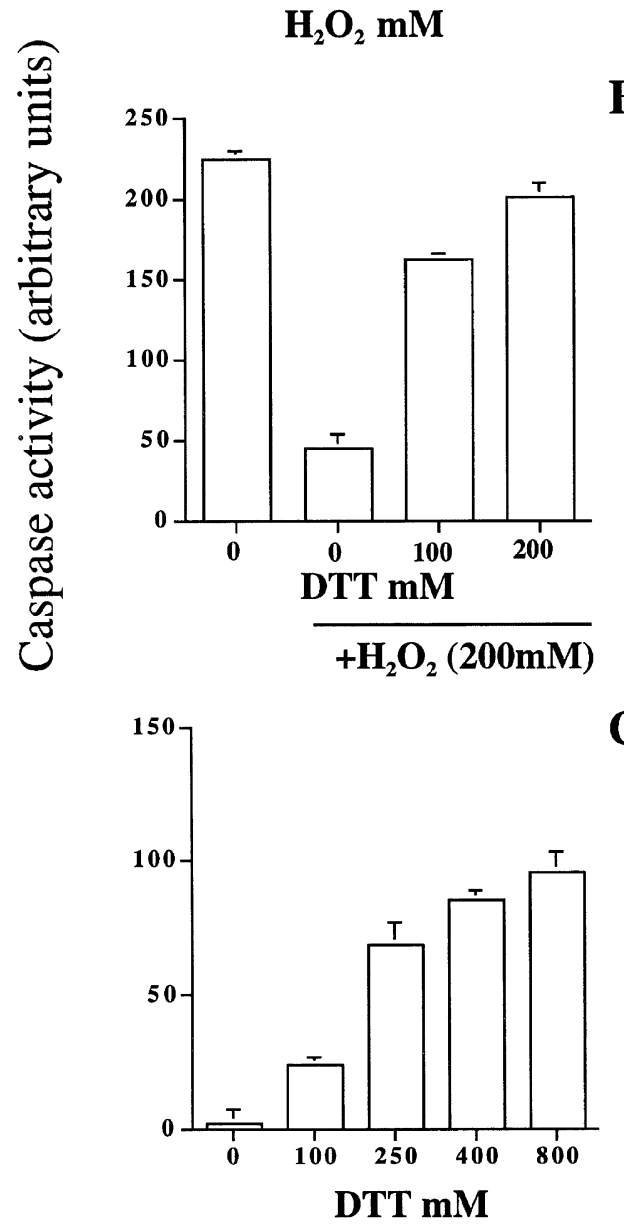

Figure 4 Effect of redox-active compounds on the caspase-3 (-like) activities of Fas treated Jurkats and retinal cell cultures. (A) Jurkat cells were treated with $300 \mathrm{ng} / \mathrm{ml}$ anti-human Fas IgM for $4 \mathrm{~h}$ and then lysed. Lysates were incubated with the indicated concentration of hydrogen peroxide (50 to $800 \mathrm{mM}$ ) for $30 \mathrm{~min}$ at $4^{\circ} \mathrm{C}$ followed by an assay for caspase-3(-like) activity involving the measurement of pNA release from the substrate DEVD-pNA. (B) Peroxide treated $\left(200 \mathrm{mM}\right.$ for $30 \mathrm{~min}$ at $4^{\circ} \mathrm{C}$ ) apoptotic Jurkat cell lysates were then incubated with the indicated concentration of the thiol reducing agent DTT (100 and $200 \mathrm{mM}$ for $30 \mathrm{~min}$ at $4^{\circ} \mathrm{C}$ ) and caspase-3 (-like) activity measured again. DTT reverses peroxide inactivation of caspase-3 (-like) caspases. (C) Retinal cells, cultured for $12 \mathrm{~h}$, were lysed in an identical manner and incubated with the indicated concentration of DTT (100 to $800 \mathrm{mM}$ for $30 \mathrm{~min}$ at $4{ }^{\circ} \mathrm{C}$ ) before caspase-3 (-like) activity was measured. Addition of DTT significantly restored caspase-3 (-like) activity in lysates taken from retinal cells undergoing cell death. These results are representative of three separate experiments \pm S.E. 
Table 1 Effects of antioxidants on retinal cell death in vitro

\begin{tabular}{lc}
\hline Treatment & \% Cell death at $\mathbf{1 2} \mathbf{h}$ \\
\hline None & $55 \pm 6$ \\
PDTC $(40 \mu \mathrm{M})$ & $6 \pm 5$ \\
$\mathrm{ZnCl}_{2}(500 \mu \mathrm{M})$ & $4 \pm 5$ \\
\hline
\end{tabular}

Percentage cell death was determined by measuring phosphatidylserine exposure using FITC conjugated annexin-V as described in Materials and Methods been proposed to be an early event in apoptosis, however it appears that mitochondrial depolarisation is not necessary for apoptosis in all cell types. In this study, loss of mitochondrial membrane potential, as monitored by the mitochondrial specific probe JC-1 (Figure $5 \mathrm{~A}$ ), occurs after a significant ROS generation during retinal cell apoptosis. The kinetics of mitochondrial depolarisation appear to follow more closely other apoptotic events such as PS exposure (Figure 1A) and

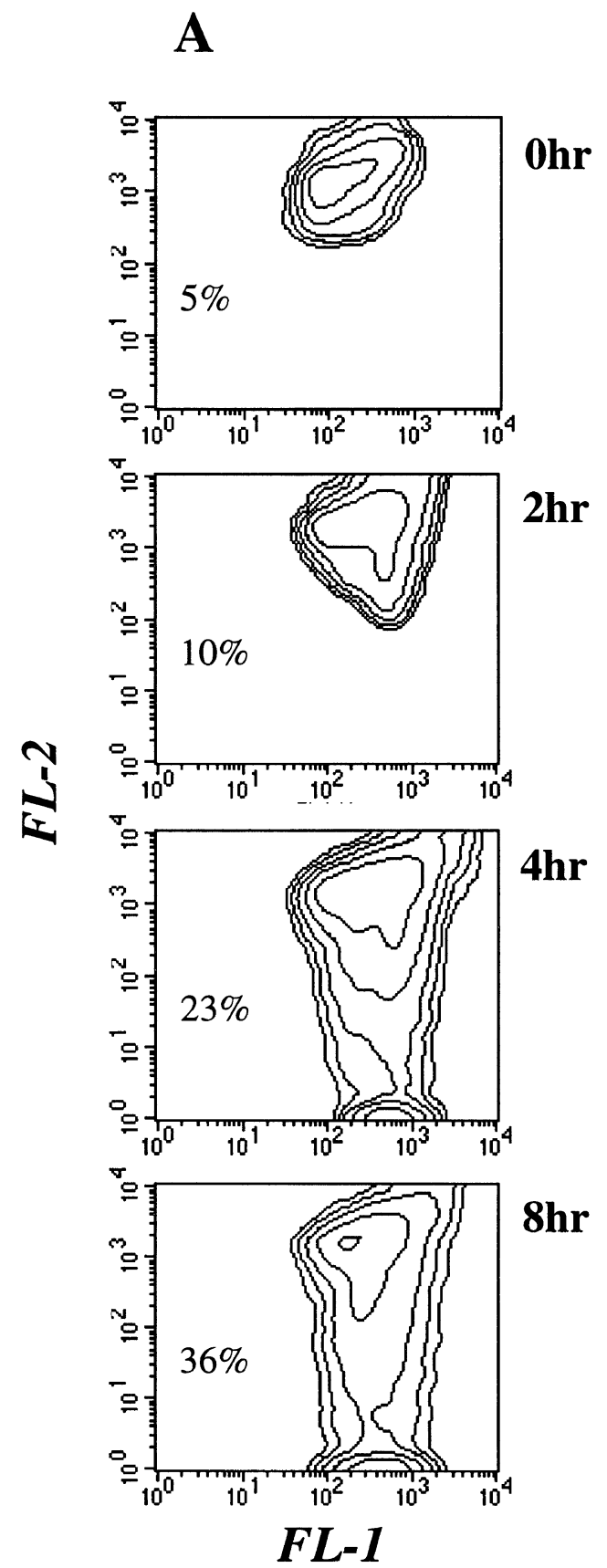

B

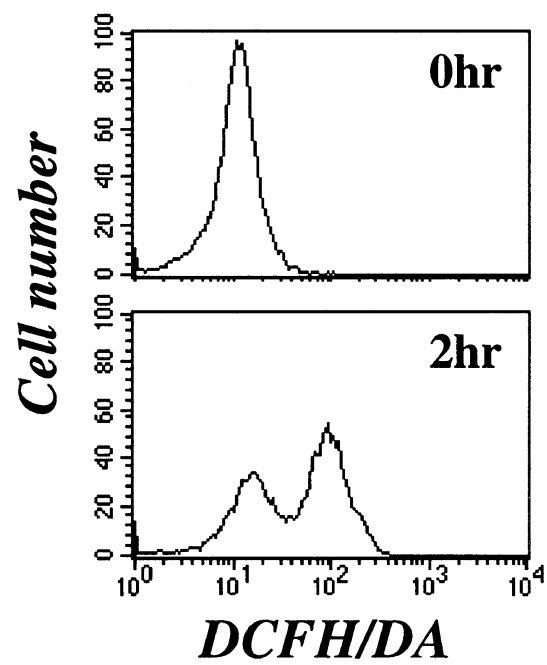

Figure 5 ROS generation precedes loss of mitochondrial membrane potential during retinal cell death in vitro. (A) Flow cytometric analysis of mitochondrial membrane potential in retinal cells as assessed by JC- 1 fluorescence. JC- 1 fluorescence in the FL- 1 channel increases as mitochondrial membrane potential drops while its fluorescence in the FL-2 channel decreases. Percentage numbers indicate proportion of retinal cells with depolarised mitochondria at 2,4 , and $8 \mathrm{~h}$, and immediately after isolation $(\mathrm{O})$. (B) Intracellular ROS levels of retinal cells immediately after isolation $(0 \mathrm{~h})$ and following $2 \mathrm{~h}$ of culture were measured using the fluorescent probe DCFH/ DA. Increases in fluorescence due to DCFH/DA indicates increased intracellular ROS. These results are representative of three individual experiments 
cell shrinkage (Figure 1B). These data suggest that mitochondrial membrane depolarisation may result from direct ROS/oxidative damage to the mitochondria rather than the action of caspases.

\section{Discussion}

Despite the central role attributed to the caspases in apoptosis, emerging evidence now suggests that this family of proteases may not control the cellular commitment to programmed cell death in all cells. Caspase-independent cell death has now been described in several models of apoptosis including glucocorticoid induced thymocyte cell death, ${ }^{30}$ growth factor withdrawal in haematopoietic cell death, ${ }^{32}$ etoptoside, ${ }^{31}$ ceramide $^{42}$ and nitric oxide (NO) induced death, ${ }^{36}$ as well as cell death due to the enforced expression of $\mathrm{Bax},{ }^{43} \mathrm{Bak}^{34} \mathrm{C}-\mathrm{Myc},{ }^{34}$ the adenovirus death factor E4orf $4^{44}$ and CD $45^{45}$ crosslinking. In many of these cases the use of caspase inhibitors prevented most features of apoptotic cell death, but several morphological and biochemical markers of apoptosis, including PS exposure, ${ }^{44,46}$ loss of mitochondrial transmembrane potential, ${ }^{31,42-45}$ chromatin condensation, ${ }^{43,44,47,48}$ membrane blebbing ${ }^{34,44}$ and cytoplasmic shrinkage ${ }^{44,48}$ were retained. These studies have demonstrated that, at least in these models, several apoptotic events are not regulated by the caspases, and that while caspase activity may be sufficient for apoptotic cell death, it is not always necessary. This study describes a retinal cell apoptosis pathway in vitro which does not involve caspase activity. The lack of caspase activity as these cells die is evidenced by the lack of caspase-3 activation (Figure 2), the absence of PARP cleavage (data not shown) - a substitute for several members of the caspase family ${ }^{49}$ - as well as the failure of several, broad spectrum caspase inhibitors to prevent or alter the characteristics and kinetics of the cell death observed (Figure 2 and data not shown).

The retinal cell death described in this study retains key characteristics of apoptotic cell death in the absence of caspase activity. These include the externalisation of PS to the outer leaflet of the plasma membrane, mitochondrial depolarisation, DNA strand nicking and cell shrinkage. The early detection of increased ROS generation here, and the previous demonstration that ROS act as mediators of photoreceptor apoptosis in vitro, ${ }^{38}$ suggest that the caspase-independent apoptosis observed in retinal cells in vitro is driven by oxidative stress. This is further supported by the ability of antioxidants to prevent retinal and photoreceptor apoptosis in vitro ${ }^{38}$ (and Table 1). Although PS exposure on the outer plasma membrane has been reported to be dependent on caspase activity, ${ }^{50}$ alternative regulatory mechanisms for this process have been proposed. Indeed, studies using erythrocytes have shown the specific externalisation of PS induced by oxidative stress, ${ }^{51}$ while in haematopoietic and lymphocytic cells direct PS oxidation has been observed prior to externalisation during apoptosis. ${ }^{52,53}$ These reports provide evidence for the regulation of PS exposure and subsequent cell corpse engulfment by ROS, and suggest a mechanism for the PS exposure observed in the absence of caspase activity during retinal cell death in vitro.
The absence of low molecular weight, internucleosomal DNA fragmentation in retinal cell death in vitro may be associated with the apparent role of caspases in this apoptotic event. The only apoptosis specific pathway for the internucleosomal fragmentation of nuclear DNA described to date involves a caspase activated DNase (CAD) whose endogenous inhibitor (ICAD) must be cleaved in a caspase dependent manner. ${ }^{28}$ The lack of low molecular DNA fragmentation observed in this study may be due to the absence of caspase activity during cell death. The labelling of retinal nuclei using the terminal dUTP nick end labelling assay, however, indicates the presence of DNA nicks or possibly high molecular weight DNA fragmentation during cell death. ${ }^{54}$ It is possible that other endonucleases, not under the direct regulation of the caspases, are also involved in the initial stages of DNA degradation during programmed cell death. ${ }^{55}$

The loss of mitochondrial membrane potential in retinal cell death in vitro follows other events such as ROS generation and PS exposure. Loss of mitochondrial membrane potential has been ascribed a central role in the apoptotic process and has been proposed to act as a forward feeding loop for the activation of the downstream caspases (i.e. those containing short prodomains such as caspase-3, -6, and -7) through release of cytochrome $\mathrm{c}$ from the mitochondrial intermembrane space. ${ }^{56}$ Active caspases may induce further mitochondrial alterations, including membrane rupture and the release of additional caspases and caspase activating factors culminating in a caspase activity amplification step. ${ }^{57}$ The lack of caspase activity in the retinal cell death discussed here appears to relegate mitochondrial depolarisation to a later stage in the death pathway, possibly as a result of direct oxidative damage. Thus, the role of mitochondria as primary mediators of programmed cell death would appear to be dependent upon the ability of a given cell or stimulus to initiate caspase activation.

In this present study we have demonstrated that the failure of caspase inhibitors to prevent or alter retinal cell apoptosis in vitro is due to the lack of caspase activation during the death process in the first instance. The previously established role for ROS and loss of intracellular antioxidant defence such as glutathione in retinal cell apoptosis in vitro ${ }^{38}$ may provide an explanation for the lack of caspase activation during programmed cell death in this model. The presence of an essential thiol group in the active site of the caspases would be predicted to render these enzymes redox sensitive. ${ }^{58}$ The ability of DTT, a thiol reducing agent, to restore caspase activity in retinal cell lysates, as shown here, strongly suggests that caspase inactivation in this model is due to oxidation of the cysteine residue in the active site. This indicates that increased ROS generation during retinal cell death in vitro prevents activation of the caspases but allows the activation of a caspase-independent apoptotic pathway.

This study and other studies have shown the redox modification of caspase activity through the use of oxidants such as peroxide ${ }^{40}$ (and Figure 4), diamide ${ }^{59}$ and the dithiocarbamate disulfides. ${ }^{60}$ It is becoming evident that the 
cellular reducing environment maintained by endogenous antioxidants such as glutathione and thioredoxin ${ }^{59}$ plays an important role in the ability of the caspases to execute the effector stages of the apoptotic program.

In conclusion, this study provides evidence for ROS driven, caspase-independent apoptosis, retaining key features such as externalisation of PS, cell shrinkage and DNA nicking. The failure of caspase inhibitors to prevent apoptosis suggests that therapeutic intervention at the level of the caspases may not be sufficient to prevent apoptosis in retinal degenerations such as RP. It has previously been reported that the baculoviral caspase inhibitor, p35, was not only capable of preventing apoptosis in retinal degenerative Drosophila mutants, but also of maintaining visual functionality. ${ }^{61}$ Interestingly, a recent report has attributed an anti-oxidant property to $\mathrm{p} 35^{62}$ suggesting that cell survival in these retinal degenerative mutants may not only require inhibition of the effectors of the cell death machinery, but also of the initiating signals. In light of this view, and as our findings demonstrate, the use of antioxidants may be of more therapeutic benefit in the prevention of retinal degeneration in RP than inhibitors of the caspases.

\section{Materials and Methods}

\section{Tissue culture}

Adult C57/BL mice were used in all experiments. Retinal dissection and cell culture preparation were carried out according to the method previously described. ${ }^{37}$ Briefly, enucleated eyes were placed in Hanks' basal salt solution (HBSS) and any mesenchyme removed. Using a watchmakers forceps, the choroid, sclera and pigmented epithelium were removed. The retina was then separated from the vitreous and lens and placed in cold medium. Tissue dissociation was achieved in a $0.25 \%$ trypsin solution (Gibco-BRL, Paisley, UK). Cells were seeded in multi-well plates and cultured in a previously described chemically defined Dulbecco's modified eagles (DME) medium ${ }^{37}$ (high pyruvate, low glucose) (Gibco-BRL, UK)

\section{Cell lines/reagents}

Jurkat T-cells were maintained in RPMI containing 10\% FCS. 32D cells were cultured in RPMI containing 10\% FCS and 10\% WEHI conditioned media. Agents used to induce apoptosis were anti-human Fas $(300 \mathrm{ng} / \mathrm{ml})$ (Upstate Biotech New York, USA) and exposure to ultraviolet (UV) irradiation (10 min). Caspase inhibitors employed were zVAD-fmk (Enzyme System Products, CA, USA), DEVD-CHO (Bachem, Essex, UK) and BD-fmk (Bachem, Essex, UK).

\section{Measurement of PS exposure}

The exposure of PS on the extracellular surface of the plasma membrane was monitored by the binding of Annexin-V-FITC following the manufacturer's instructions (BenderMed Systems, Vienna, Austria). Cells were simultaneously stained with $50 \mu \mathrm{g} / \mathrm{ml}$ propidium iodide (PI) prior to analysis on a FACScan flow cytometer (Becton Dickinson, USA) using an excitation of $488 \mathrm{~nm}$. Fluorescence due to FITC and PI was measured at 530 and $590 \mathrm{~nm}$ respectively. Low fluorescence debris was gated out prior to analysis.

\section{Assessment of DNA integrity}

Double stranded DNA fragmentation was examined as previously described. ${ }^{63}$ Briefly, cells $\left(1 \times 10^{6} / \mathrm{ml}\right)$ were pelleted by centrifugation at $200 \times g$ for $5 \mathrm{~min}$ at room temperature. The pellets were resuspended in lysis buffer (20 mM EDTA, $100 \mathrm{mM}$ Tris (pH 8.0), $0.8 \%(\mathrm{w} / \mathrm{v})$ sodium lauryl sarcosinate) and $10 \mu \mathrm{l}$ RNase A $(1 \mathrm{mg} / \mathrm{ml}$ in $0.1 \mathrm{M}$ sodium acetate, $0.3 \mathrm{mM}$ EDTA $\mathrm{pH} 4.8$ ) and incubated at $37^{\circ} \mathrm{C}$ for $1.5-2 \mathrm{~h}$. Ten $\mu \mathrm{l}$ of proteinase $\mathrm{K}(20 \mathrm{mg} / \mathrm{ml}$ in distilled water) was then added and extracts incubated overnight at $50^{\circ} \mathrm{C}$. Electrophoresis was carried out using $1.5 \%$ agarose gels and DNA was visualised under UV light following staining with ethidium bromide.

\section{Terminal deoxy-uridine (dUTP) nick-end labelling (TUNEL)}

In situ terminal dUTP nick end labelling was performed as previously described. ${ }^{37}$ Briefly, cells were fixed in $1 \%$ para-formaldehyde and stored overnight at $-20^{\circ} \mathrm{C}$ in $70 \%$ ethanol. After washing in phosphate buffer saline (PBS), cells were re-suspended in $50 \mu \mathrm{l}$ of reaction mixture containing $0.1 \mathrm{mM}$ dithiothreitol (DTT), $0.05 \mathrm{mg} / \mathrm{ml} \mathrm{BSA}$, $2.5 \mathrm{mM} \mathrm{CoCl}, 0.4 \mathrm{mM}$ bio-16-dUTP and $0.1 \mathrm{U} / \mathrm{ml}$ terminal deoxynucleotidyl transferase (TdT) in $0.1 \mathrm{M} \mathrm{Na}$ cacodylate $(\mathrm{pH} 7.0)$ buffer. This mixture was incubated at $37^{\circ} \mathrm{C}$ for $30 \mathrm{~min}$. Cells were then washed in PBS and re-suspended in $100 \mu \mathrm{l}$ of staining buffer containing $2.5 \mathrm{mg} / \mathrm{ml}$ fluoresceinated avidin, $4 \times$ concentrated saline-sodium citrate buffer $(0.3 \mathrm{M}), 0.1 \%$ Triton X-100 and $5 \%(\mathrm{w} / \mathrm{v})$ low-fat dried milk. Cells were then incubated for $30 \mathrm{~min}$ at room temperature in the dark before washing in PBS. Bio-16-dUTP and TdT enzyme from Boehringer Mannheim (Mannheim, Germany). Samples were read on a Becton Dickinson FACScan using excitation and emission wavelengths of 488 and $530 \mathrm{~nm}$ respectively.

\section{Nuclear morphology analysis}

Cells were stained in a $1 \mu \mathrm{g} / \mathrm{ml}$ DAPI/methanol (Sigma, Dublin, Ireland) solution for $15 \mathrm{~min}$ at $37^{\circ} \mathrm{C}$. Following washing in PBS, cells were mounted in mowiol (Calbiochem, Nottingham, UK) and viewed under a fluorescence microscope (Nikon Eclipse E600) using a DAPI filter (excitation $340-380 \mathrm{~nm}$, emission $435-485 \mathrm{~nm}$ ).

\section{Western blot analysis}

Anti-caspase-3 rabbit polyclonal antibody obtained from Upstate Biotech (New York, USA) was used for immunoblot detection of caspase-3. Cells were lysed in RIPA buffer $(50 \mathrm{mM}$ Tris- $\mathrm{HCl} \mathrm{pH} 7.4$ $1 \% \mathrm{NP} 40,0.25 \%$ sodium deoxycholate, $150 \mathrm{mM} \mathrm{NaCl}, 1 \mathrm{mM}$ EGTA, $1 \mathrm{mM}$ sodium orthovanadate, $1 \mathrm{mM}$ sodium fluoride) containing antipain $(1 \mu \mathrm{g} / \mathrm{ml})$, aprotinin $(1 \mu \mathrm{g} / \mathrm{ml})$, chymostatin $(1 \mu \mathrm{g} / \mathrm{ml})$, leupeptin $(0.1 \mu \mathrm{g} / \mathrm{ml})$, pepstatin $(1 \mu \mathrm{g} / \mathrm{ml})$ and PMSF $(0.1 \mathrm{mM})$. Equivalent amounts of protein, as determined by the Bio-Rad Protein Assay (Bio-Rad, Hemel Hempstead, UK) using bovine serum albumin as a standard, were resolved using SDS-PAGE followed by transfer to nitrocellulose membrane (Schleicher and Schuell, Dassel, Germany). The membrane was blocked using phosphate buffered saline (PBS) containing $5 \%$ fat free dried milk before incubation with anti-caspase-3 antibody (1:1000) overnight. Blots were washed with PBS containing $0.01 \%$ Tween 20 (PBS-T), incubated with peroxidase conjugated secondary antibody, and washed once more with PBS-T. Membrane development was achieved using Enhanced Chemiluminescence (ECL) (Amersham, Buckinghamshire, UK). 


\section{Determination of DEVD-pNA cleavage}

The measurement of DEVD-pNA (Calbiochem, Nottingham, UK) cleavage was performed in a spectrophotometric assay by monitoring the liberation of $p N A$ due to caspase activity. Cells were lysed using a non-denaturing buffer (10 mM HEPES pH 7.4, $50 \mathrm{mM} \mathrm{NaCl}, 2 \mathrm{mM}$ $\mathrm{MgCl}_{2}, 5 \mathrm{mM}$ EGTA, $1 \mathrm{mM}$ PMSF, $1 \mu \mathrm{g} / \mathrm{ml}$ leupeptin, $1 \mu \mathrm{g} / \mathrm{ml}$ aprotinin). Cell lysates were then incubated in an equal volume of $2 \times$ reaction buffer $(50 \mathrm{mM}$ HEPES $\mathrm{pH}$ 7.4, 0.5\% CHAPS, $25 \mathrm{mM}$ DTT) and $50 \mu \mathrm{M}$ DEVD-pNA substrate at $37^{\circ} \mathrm{C}$ in a microtiter plate. Cleavage of the peptide substrate DEVD-pNA was monitored by pNA liberation in a SpectraMax-340 plate reader (Molecular Devices, CA, USA) by measuring absorption at $405 \mathrm{~nm}$.

\section{Analysis of intracellular ROS generation}

Peroxide levels were determined using the previously described method of Hockenbery and co-workers. ${ }^{64}$ Briefly, cells $\left(5 \times 10^{5}\right)$ were loaded with $5 \mu \mathrm{M} \mathrm{DCFH/DA} \mathrm{(Molecular} \mathrm{Probes,} \mathrm{Netherlands)} \mathrm{for} 1 \mathrm{~h}$ at $37^{\circ} \mathrm{C}$ prior to measurement on a Becton Dickinson FACScan flow cytometer with excitation and emission settings of 488 and $530 \mathrm{~nm}$ (FL-1) respectively.

\section{Analysis of mitochondrial membrane potential $\left(\Delta \Psi_{\mathrm{m}}\right)$}

Mitochondrial membrane disruption was analyzed using JC-1 (Molecular Probes, Netherlands). JC-1 is a dual emission probe with increased fluorescence at $530 \mathrm{~nm}(\mathrm{FL}-1)$ and reduced fluorescence at $590 \mathrm{~nm}$ (FL-2) associated with a decrease in mitochondrial transmembrane potential. JC-1 was used at $5 \mu \mathrm{g} / \mathrm{ml}$ from a $5 \mathrm{mg} / \mathrm{ml}$ stock prepared in DMSO. Cells were incubated with JC-1 for $15 \mathrm{~min}$ at $37^{\circ} \mathrm{C}$ and fluorescence measured in both FL-1 and FL-2 channels on a Becton Dickinson FACScan with an excitation of $488 \mathrm{~nm}$.

\section{Acknowledgements}

The authors acknowledge Dr. Sharon McKenna and Prof. Pete Humphries for useful discussions and Karen Keeshan for 32D cells. This work was supported by RP Ireland Fighting Blindness and the Irish Health Research Board.

\section{References}

1. Draganow M, Faull R, Lawlor P, Beilharz E, Singleton K, Walker E and Mee E (1995) In situ evidence for DNA fragmentation in Huntingtons disease striatum and Alzheimers disease temporal lobes. Neuroreport 6: 1053-1057

2. Troost D, Aten J, Morsink F and de Jong J (1995) Apoptosis in amyloid lateral sclerosis is not restricted to motor neurons. Bcl-2 expression is increased in unaffected post-central gyrus. Neuropathol. Appl. Neurobiol. 21: 498-504

3. Li Y, Chopp M, Jiang N, Yao F and Zaloga C (1995a) Temporal profile of in situ DNA fragmentation after transient middle cerebral artery occlusion in the rat. J. Cereb. Blood Flow Metab. 15: 3989-3997

4. Chang G, Hao Y and Wong F (1993) Apoptosis: final common pathway of photoreceptor death in rd, rds and rhodopsin mutant mice. Neuron 11: 595-605

5. Potera-Cailliau C, Sung C, Nathans J and Adler R (1993) Apoptotic photoreceptor cell death in mouse models of retinitis pigmentosa. Proc. Natl. Acad. Sci. U.S.A. 91: $974-978$

6. Li Z and Milam A (1995) Apoptosis in retinitis pigmentosa. In: Degenerative diseases of the retina. Anderson R, LaVail M and Hollyfield J, eds. (New York: Plenum Press) pp 1-8

7. Dryja TP and Li T (1995) Molecular genetics of retinitis pigmentosa. Hum. Mol. Genet. 4: $1739-1743$
8. Maw MA, Kennedy B, Knight A, Bridges R, Roth KE, Mani EJ, Mukkadan JK, Nancarrow D, Crabb JW and Denton MJ (1997) Mutation of the gene encoding cellular retinaldehyde-binding protein in autosomal recessive retinitis pigmentosa. Nat. Genet. 17: 198-200

9. GuSM, Thompson DA, Srikumari CR, Lorenz B, FinckhU, Nicoletti A, Murthy KR, Rathmann M, Kumaramanickavel G, Denton MJ and Gal A (1997) Mutations in RPE65 cause autosomal recessive childhood-onset severe retinal dystrophy. Nat. Genet. 17: $194-197$

10. Ellis HM and Horvitz HR (1986) Genetic control of programmed cell death in the nematode C. elegans. Cell 44: 817-829

11. Hengartner MO and Horvitz HR (1994) C. elegans cell survival gene ced-9 encodes a functional homolog of the mammalian proto-oncogene bcl-2. Cell 76: $665-676$

12. Zou H, Li Y, Liu X and Wang X (1999) An Apaf-1/cytochrome-c multimeric complex is a functional apoptosome that activates procaspase-9. J. Biol. Chem. 274: $11549-11556$

13. Yuan J, Shaham S, Ledoux S, Ellis HM and Horvitz HR(1993) The C. elegans cell death gene ced- 3 encodes a protein similar to mammalian interleukin- 1 beta converting enzyme. Cell 75: 641-652

14. Fernandes-Alnemri T, Litwack $G$ and Alnemri ES (1994) CPP32 a novel human apoptotic protein with homology to $C$. elegans cell death ced-3 and mammalian interleukin-1B converting enzyme. J. Biol. Chem. 269: 30761-30764

15. Nunez G, Benedict MA, Hu Y and Inohara N (1998) Caspases: the proteases of the apoptotic pathway. Oncogene 17: $3237-3245$

16. Boldin MP, Goncharov TM, Goltsev YV and Wallach D (1996) Involvement of Mach, a novel MORT1/FADD-interacting protease, in Fas/APO-1- and THF receptor-induced cell death. Cell 85: 803-815

17. Li P, Nijhawan D, Budihardjo I, Srinivasula SM, Ahmad M, Alnemri ES and Wang X (1997) Cytochrome $c$ and dATP-dependent formation of Apaf-1/caspase-9 complex initiates an apoptotic protease cascade. Cell 91: 479-489

18. Hu Y, Benedict MA, Wu D, Inohara N and Nunez G (1998) Bcl-XL interacts with Apaf-1 and inhibits Apaf-1-dependent caspase-9 activation. Proc. Natl. Acad. Sci. U.S.A. 95 : $4386-4391$

19. Finucane DM, Bossy-Wetzel E, Waterhouse NJ, Cotter TG and Green DR(1999) Bax-induced caspase activation and apoptosis via cytochrome $c$ release from mitochondria is inhibitable by Bcl-xL. J. Biol. Chem. 274: 2225-2233

20. Slee EA, Harte MT, Kluck RM, WolfBB, Casiano CA, Newmeyer DD, Wang H-G, Reed JC, Nicholson DW, Alnemri ES, Green DR and Martin SJ (1999) Ordering the cytochrome c-initiated caspase cascade: Hierarchical activation of caspases-2, $-3,-6,-7,-8$ and -10 in a caspase-9-dependent manner. J. Cell Biol. 144: $281-292$

21. Stroh C and Schulze-Osthoff K (1998) Death by a thousand cuts: an ever increasing list of caspase substrates. Cell Death Differ. 5: 997-1000

22. Song Q, Kees-Miller SP, Kumar S, Zhang N, Chan DW, Smith GCM, Jackson SP, Alnemri ES, Litwack G, Khanna KK and Lavin MF (1996) DNA dependent protein kinase catalytic subunit: a target for an ICE like protease in apoptosis. EMBO J. 15: $3238-3246$

23. Casciola-Rosen LA, Miller DK, Anhalt GJ and Rosen A (1994) Specific cleavage of the $70-\mathrm{kDa}$ protein component of the $\mathrm{U} 1 \mathrm{small}$ nuclear ribonucleoprotein is a characteristic biochemical feature of apoptotic cell death. J. Biol. Chem. 269: 30757-30760

24. Lazebnik YA, Kaufmann SH, Desnoyers S, Poirier GG and Earnshaw WC (1994) Cleavage of poly(ADP-ribose) polymerase by a proteinase with properties like ICE. Nature $371: 346-347$

25. Leist M, Single B, Castoldi AF, Kuhnle S and Nicotera P (1997) Intracellular adenosine triphosphate (ATP) concentration: a switch in the decision between apoptosis and necrosis. J. Exp. Med. 185: 1481-1486

26. Bokoch GM (1998) Caspase mediated activation of PAK2 during apoptosis: proteolytic kinase activation as a general mechanism of apoptotic signal transduction? Cell Death Differ. 5: 637-645

27. Porter AG, Ng Pand Janicke RU (1997) Death substrates come alive. BioEssays 19: $501-507$

28. Enari M, Sakahira H, Yokoyama H, Okawa K, Iwamatsu A and Nagata S (1998) A caspase-activated DNase that degrades DNA during apoptosis, and its inhibitor ICAD. Nature 391: 43-50

29. Villa P, Kaufmann SH and Earnshaw WC (1997) Caspases and caspase inhibitors. TIBS. 22: 388-393 
30. Hirsch T, Marchetti P, Susin SA, Dallaporta B, Zamzami N, Marzo I, Geuskens M and Kroemer G (1997) The apoptosis-necrosis paradox. Apoptogenic proteases activated after mitochondrial permeability transition determine the mode of cell death. Oncogene 15: 1573-1581

31. Brunet CL, Gunby RH, Benson RSP, Hickman JA, Watson AJM and Brady G (1998) Commitment to cell death measured by loss of clonegenicity is separable from the appearance of apoptotic markers. Cell Death Differ. 5: 107-115

32. Ohta T, Kinoshita T, Naito M, Nozaki T, Masutani M, Tsuruo T and Miyajima A (1997) Requirement of the caspase-3/CPP32 protease cascade for apoptotic death following cytokine deprivation in hematopoietic cells. J. Biol. Chem. 272: $23111-23116$

33. Amarante-Mendes GP, Finucane DM, Martin SJ, Cotter TG, Salvesen GS and Green DR (1998) Anti-apoptotic oncogenes prevent caspase-dependent and independent commitment for cell death. Cell Death Differ. 5: 298-306

34. McCarthy NJ, Whyte MKB, Gilbert CS and Evan GI (1997) Inhibition of ced-3/ ICE-related proteases does not prevent cell death induced by oncogenes, DNA damage, or the Bcl-2 homologue Bak. J. Cell Biol. 136: 215-227

35. Sarin A, Wu M-L and Henkart PA (1996) Different interleukin-1 $\beta$ converting enzyme (ICE) family protease requirements for the apoptotic death of $T$ lymphocytes triggered by diverse stimuli. J. Exp. Med. 184: 2445-2450

36. Okuno S, Shigeomi S, Ito T, Nomura M, Hamada E, Tsujimoto Y and Matsuda H (1998) Bcl-2 prevents caspase-independent cell death. J. Biol. Chem. 273: $34272-34277$

37. Carmody RJ, McGowan AJ and Cotter TG (1998) Rapid detection of rod photoreceptor apoptosis by flow cytometry. Cytometry 33: 89-92

38. Carmody RJ, McGowan AJ and Cotter TG (1999) Reactive Oxygen species as mediators of photoreceptor apoptosis in vitro. Exp. Cell Res. 248: 520-530

39. Krajewska M, Wang HG, Krajewska S, Zapata JM, Shabaik A, Gascoyne R and Reed JC (1997) Immunohistochemical analysis of in vivo patterns of expression of CPP32 (Caspase-3), a cell death protease. Cancer Res. 57: 1605-1613

40. Hampton MB and Orrenius S (1997) Dual regulation of caspase activity by hydrogen peroxide: implications for apoptosis. FEBS Lett. 414: 552-556

41. Nobel SI, Burgess DH, Zhivotsky B, BurkittMJ, Orrenius S and Slater AFG (1997) Mechanism of dithiocarbamate inhibition of apoptosis: thiol oxidation by dithiocarbamate disulfides directly inhibits processing of the caspase-3 proenzyme. Chem. Res. Toxicol. 10: 636-643

42. DeMaria R, Lenti L, Malisan F, d'Agostino F, Tomassini B, Zeuner A, Rippo MR and Testi $R$ (1997) Requirement for GD3 ganglioside in CD95- and ceramideinduced apoptosis. Science 277: 1652-1655

43. Xiang J, Chao DT and Korsmeyer SJ (1996) BAX-induced cell death may not require interleukin $1 \beta$-converting enzyme-like proteases. Proc. Natl. Acad. Sci. U.S.A. 93: $14559-14563$

44. Lavoie JN, Nguyen RC, Marcellus RC, Branton RE and Shore GC (1998) E4orf4, a novel adenovirus death factor that induces p53-independent apoptosis by a pathway not inhibited by zVAD-fmk. J. Cell Biol. 140: 637-645

45. Lesage S, Steff A-M, Philippoussis F, Page M, Trop S, Mateo V and Hugo P (1997) $\mathrm{CD} 4^{+} \mathrm{CD} 8^{+}$thymocytes are preferentially induced to die following CD45 cross-linking, through a novel apoptotic pathway. J. Immunol. 159: 476-477

46. Hampton MB, Fadeel B and Orrenius S (1998) Redox regulation of the caspases during apoptosis. Ann. N.Y. Acad. Sci. 854: 328-335

47. Monney L, Otter I, Olivier R, Ozer HL, Haas AL, Omura S and Borner C (1998) Defects in the ubiquitin pathway induce caspase-independent apoptosis blocked by Bcl-2. J. Biol. Chem. 273: 6121-6131
48. Zhang J, Reedy MC, Hannun YA and Obeid LM (1999) Inhibition of caspases inhibits the release of apoptotic bodies: $\mathrm{Bcl}-2$ inhibits the initiation of formation of apoptotic bodies in chemotherapeutic agent-induced apoptosis. J. Cell Biol. 145: $99-108$

49. Kidd VJ (1998) Proteolytic activities that mediate apoptosis. Annu. Rev. Physiol. 60: $533-573$

50. Martin SJ, Finucane DM, Amarante-Mendes GP, O'Brien GA and Green DR (1996) Phosphatidylserine externalisation during CD95-induced apoptosis of cells and cytoplasts requires ICE/CED-3 protease activity. J. Biol. Chem. 271: 28753-28756

51. Arduino A, Stern A, Storto S, Belfiglio M, Mancinelli G, Scurti R and Federici G (1989) Effect of oxidative stress on membrane phospholipid and protein organisation in human erythrocytes. Arch. Biochem. Biophys. 273: 112-120

52. Fabisiak JP, Kagan VE, Ritov VB, Johnson DE and Lazo JS (1997) Bcl-2 inhibits selective oxidation and externalisation of phosphatidylserine during paraquatinduced apoptosis. Am. J. Physiol. 272: 675-684

53. Fabisiak JP, Tyurina YY, Tyurin VA, Lazo JS and Kagan VE (1998) Random versus selective membrane phospholipid oxidation in apoptosis: role of phosphatidylserine. Biochemistry 37: 13781-13790

54. Gorczya W, Bruno S, Darzynkiewicz RJ, Gong J and Darzynkiewicz Z (1992) DNA strand breaks occurring during apoptosis: Their early in situ detection by the terminal deoxynucleotidyl transferase and nick translation assays and prevention by serine protease inhibitors. Int. J. Oncol. 1:639-648

55. Hughes Jr FM, Evans-Storms RB and Cidlowski JA (1998) Evidence that noncaspase proteases are required for chromatin degradation during apoptosis. Cell Death Differ. 5: 1017-1027

56. Green D and Kroemer G (1998) The central executioners of apoptosis: caspases or mitochondria? Trends Cell Biol. 8: 267-271

57. Marzo I, Susin SA, Petit PX, Ravagnan L, Brenner C, Larochette N, Zamzami N and Kroemer G (1998) Caspases disrupt mitochondrial membrane barrier function. FEBS Lett. 427: 198-202

58. AlnemriE, Livingston DJ, Nicholson DW, Salvesen G, Thornberry NA, Wong WW and Yuan J (1996) Human ICE/CED-3 protease nomenclature. Cell 87: 171

59. Ueda S, Nakamura H, Matsutani H, Sasada T, Ynehara S, Takabayashi A, Yamaoka Y and Yodoi J (1998) Redox regulation of caspase-3(-like) protease activity: regulatory roles of thioredoxin and cytochrome c. J. Immunol. 161 $6689-6695$

60. Nobel CSI, Kimland M, Nicholson DW, Orrenius S and Slater AFG (1997) Disulfiram is a potent inhibitor of proteases of the caspase family. Chem. Res. Toxicol. 10: 1319-1324

61. Davidson F and Steller H (1998) Blocking apoptosis prevents blindness in Drosophila degeneration mutants. Nature 391: 587-591

62. Sah NK, Taneja TK Pathak N, Begum R, Athar M and Hasnain SE (1999) The baculovirus anti-apoptotic $\mathrm{p} 35$ gene also functions via an oxidant-dependent pathway. Proc. Natl. Acad. Sci. U.S.A. 96: 4838-4843

63. McGowan AJ, Ruiz-Ruiz M, Gorman A, Lopez-Rivas A and Cotter T (1996) Reactive oxygen intermediates: Common mediators of poly(ADPribose)polymerase (PARP) cleavage and apoptosis. FEBS Lett. 392: 299-303

64. Hockenbery D, Oltvai Z, Yin X-M, Milliman C and Korsmeyer S (1993) Bcl-2 functions in an antioxidant pathway to prevent apoptosis. Cell 75: 241-250 